\title{
Intimate partner violence against women and healthcare in Australia: charting the scene
}

\author{
Violência por parceiro(a) íntimo(a) contra mulheres \\ e cuidado em saúde na Austrália: cartografando o cenário
}

Marcos Claudio Signorelli ${ }^{1}$

Angela Taft ${ }^{2}$

Pedro Paulo Gomes Pereira ${ }^{3}$

${ }^{1}$ Universidade Federal do Paraná, Campus Litoral. Rua Jaguariaíva 512/ Gabinete 06, Balneário de Caiobá. 83260-000 Matinhos PR.

sarcosina@yahoo.com.br ${ }^{2}$ Mother and Child Health Research, La Trobe University.

${ }^{3}$ Universidade Federal de São Paulo
Abstract Intimate partner violence against women is a common problem in all countries and generates a challenging agenda for the health sector. Exchanging experiences between different countries, specifically strategies to respond to this problem, can constitute a tool for stimulating debate and promoting reflection. The scope of this article is to present and reflect on aspects of the Australian health sector response to intimate partner violence, and chart the scenario that surrounds this issue. We draw on a range of methods, combining a literature review and a dialogue with different stakeholders and site visits. We describe historical, contemporary and conceptual aspects of healthcare responses to intimate partner violence in Australia. Further we present some of the strategies, public policies and innovative projects that have been developed in this field in Australia. Some of the strategies include: screening vs. case-finding; primary care approaches for dealing with all family members; respect for diversity; and new randomized trials aiming for sustainable health system change for enhanced health professional care of people experiencing intimate partner violence. Despite the limitations of this approach to such a complex theme, we hope to stimulate thinking and discussion.

Key words Intimate partner violence, Public health policies, Gender-based violence
Resumo A violência por parceiro intimo contra mulheres é comum em todos os paises, gerando desafiadora agenda para o setor saúde. A troca de experiências entre países, referente às estratégias de enfrentamento do problema, pode constituirse em subsídio para fomentar debates e promover reflexões. Este artigo pretende apresentar e refletir sobre aspectos do contexto australiano no âmbito de respostas do setor saúde à violência por parceiro íntimo, cartografando o cenário que cerca essa questão. A metodologia foi desenhada combinando pesquisa bibliográfica, diálogo com diferentes atores e visitas in loco. Foram descritos aspectos históricos, contemporâneos e conceituais acerca das respostas da saúde a violência por parceiro intimo na Austrália e apresentadas algumas estratégias, políticas públicas e projetos que vêm sendo desenvolvidos no país. Merecem relevo: rastreamento e busca ativa de casos de violência por parceiro intimo; abordagem em atenção primária com todos os membros familiares; respeito às diversidades; ensaios randomizados envolvendo mudanças na formação dos profissionais e no sistema de saúde no que tange ao cuidado de mulheres vivenciando violência por parceiro intimo. Apesar das limitações ao abordar tema tão complexo, espera-se estimular reflexões e discussões.

Palavras-chave Violência por parceiro intimo, Políticas públicas de saúde, Violência de gênero 


\section{History and context}

Intimate Partner Violence (IPV) against women is a common problem all over the world. The World Health Organization (WHO) estimates that worldwide, one in three women is or was victim of violence perpetrated by an intimate partner or ex-partner ${ }^{1}$. Different countries have wide-ranging responses to problems in the health arena, and exchanging experiences can be a great opportunity to foster local debate and action. In this article, we intend to promote an exchange between Australia and Brazil, describing some aspects of the Australian response, as well as some innovations in the context of this country.

The article originated from part of the Brazilian lead author's $\mathrm{PhD}$ study focused on health professionals responses to IPV, which included five months in Australia, supported by the Brazilian government ('CAPES Foundation'). During this period, intense literature review was undertaken, combined with the study of Australian public policies and health system program responses to IPV including those for health professionals. Dialogue with key researchers and health professionals and also site visits were carried out to improve understanding of the Australian context.

Many researchers have studied IPV in different contexts with different definitions and measures. Although difficult to measure accurately, some studies, especially the WHO multi-country studies have reported that this problem and its health damaging consequences are common in many countries, including Australia ${ }^{1,2}$.

IPV has been included in the public health agenda worldwide. In Australia, similar to Brazil, it has been recognized as a public health issue, through the active campaigns of the women's movement and subsequently from responsive policies of governments at state and federal level. The first feminist refuge for women victims of violence in Australia was established in Sydney in 1974. The number of women's refuges grew rapidly, but in the 1980s, IPV began to receive wider attention from feminists working in the government public services ('femocrats') having a key role in the women's movement in Australia ${ }^{3}$. After they oversaw a nation-wide consultation with women, IPV became a key plank of the new National Women's Health Policy ${ }^{4}$.

Initially, similar to other parts of the world, the problem in Australia was viewed by health professionals as either presenting medical symptoms or as a 'private' matter. The issue only came onto the health sector's agenda after the women's movement advocated forcefully to social services, health professionals and governments to respond adequately to the problem ${ }^{5}$. Prominent health care organizations such as the Australian Medical Association (AMA), the Royal Australian College of General Practitioners (RACGP) and the Public Health Association of Australia (PHAA) developed policies and advocacy in late 1980s and 1990s, through the lobbying of their women members.

\section{Conceptual issues}

The major cause of violence against women is predominantly the inequities caused by traditional gender relations. These gender issues are social constructs present in many different cultures and Australia is no exception. Gender studies in recent years have promoted analyses about the relationships developed between men and women, between men and between women ${ }^{6,7}$. These studies polemicize the fact that we live in a heteronormative and asymmetric society, composed of 'male' and 'female' with unequal gender roles. Female roles that are stereotypically expected of women in society include idealised motherhood, dependence on and submission to men. Such roles have contributed to the perpetuation of IPV against women by condemning women who do not conform. Other consequences stemming from this unequal relationship appear in different settings worldwide and in Australia. For example, the earnings gap between men and women who perform the same job and the absence of women in key sectors of society, especially those connected with power, such as politics or the military.

Conceptually, in Australia's academic arena, the most adopted term to refer to domestic violence against women is IPV, which we discuss further below. It differs from the term 'domestic violence' (DV) - in this specific case 'DV against women'. DV is a wide term that can be used to refer to violence or abuse (physical, psychological and/or sexual) that occurs in any relationships within households. DV can occur in homes both with men and women (with family ties or not) between fathers/mothers and children, between young and elderly. Despite reaching everyone, especially those in vulnerable situations, at whatever age, women are the primary target of DV. So, the term 'domestic violence against women' (DVAW) was born within the feminist movement, denouncing the home as dangerous for 
women $^{6,8}$. Authors in Brazil and Australia considered the domestic space one where a woman is most at risk ${ }^{9,10}$. This is the reason for the common use of DVAW. In Australia these expressions are widely used in federal public policies, because these are common political terms and highlight the risk and danger to which women are submitted at home. On the other hand, many feminists avoid the term 'domestic', because it associates the domestic space as a typically feminine domain, and this issue was hard fought by the women's movement. Additionally, it limits consideration of the many places where intimate partners may control and coerce women, e.g. in cars, in public spaces, at work and on the phone.

In this regard, some authors ${ }^{11}$ prefer the term 'wife-battering', highlighting the role of women as victims. But privileging victimization is also criticized by some feminists ${ }^{12}$, because it rigidifies women in a passive position, married, under the control of men but also because it emphasises physical abuse, while women speak more of the psychological violence. The term 'family violence' (FV) is preferred by some researchers ${ }^{13}$ and in many Australian state government funded community-based services, e.g. in the state of Victoria, where they are known as 'family violence services'. In this case, FV de-emphasises location, but emphasises that while FV can occur both inside and outside the home, it occurs always as a result of abusive relationships among members of the family. Although both terms are linked, because DV usually occurs in the family, commonly within marital relations, and FV often occurs within the household, it is relevant to highlight the differences of these concepts. FV also includes child and elder abuse and furthermore is the preferred term in Australia's indigenous communities where the extended family is emphasised.

While Australian scholars are aware of these categories, they prefer the term IPV, recently recommended by the WHO and the Centre for Disease $\mathrm{Control}^{14}$ (CDC). The definitions of IPV given by WHO is:

- Any behaviour within an intimate relationship that causes physical damage, psychological or sexual abuse to those in the relationship, and this includes physical assault, psychological abuse, forced intercourse and other forms of sexual coercion and of controlling behaviours ${ }^{1}$.

Furthermore, IPV is not associated with a specific marital status and refers to intimate relationships that can occur in either legal unions or with couples cohabiting or not cohabiting in the same home. The term also includes all kinds of sexual orientations, recognising that IPV can occur in homo, hetero and bisexual relationships. Lastly, as it references all kinds of relationships, the term is unisex, and can refer both to women or men. Nevertheless, the focus in this paper and many others is based on evidence that the great majority of IPV is perpetrated against women.

\section{Prevalence: measuring the problem}

Measuring violence in the population is a difficult task, especially IPV, because it deals with complex social situations and is also related to an intimate context ${ }^{15}$. In Australia there are some factors that make this task a bigger challenge. One of these is the huge territorial area of the country, which is almost as big as Brazil and it consequently makes more difficult any attempt at collecting data. Additionally, Australia has a wide cultural diversity. There is a significant number (around 2\%) of indigenous people and large numbers $(\sim 23 \%)$ of immigrants from different nationalities, especially in recent years from Asia.

In Australia, several population studies have been conducted to calculate IPV prevalence in a lifetime. Different approaches and distinct methodologies were employed addressing a wide variety of population samples. Some are community surveys ${ }^{16}$, while others are clinical studies ${ }^{17}$ or general practice studies ${ }^{18}$. Table 1 summarizes prevalence of IPV through national random population surveys. These results can be contrasted with Brazilian IPV prevalence, through a pioneering study ${ }^{2}$ conducted across ten different countries, supported by the WHO which included Brazil ${ }^{19}$. This study revealed the extent of the problem in two different areas of Brazil: the urban city of São Paulo (in Southeast) and rural Zona da Mata de Pernambuco (in Northeast).

This table highlights the different prevalence rates in the Australian and Brazilian contexts and suggests some potential for other scenarios. An interesting aspect of the Australian Longitudinal Study ${ }^{20}$ is that the same women were surveyed again four years after the first survey (1996 and 2000), to estimate IPV prevalence over time. This study suggests a small drop between the first and the second studies. These may be artefacts of the methods or a real decrease, nevertheless we highlight the role of such national population studies to estimate the prevalence and trends of IPV in the Australian panorama, and further to foster debate about possibilities in other contexts.

The Australian Longitudinal Women's Health Study (ALSWH) using random population data 
Table 1. Prevalence studies of IPV in Australia and Brazil

\begin{tabular}{|c|c|c|c|c|}
\hline $\begin{array}{l}\text { Country, } \\
\text { Author and } \\
\text { Year }\end{array}$ & $\begin{array}{c}\text { Sample size of women, age } \\
\text { and approach }\end{array}$ & Definitions used & $\begin{array}{c}\text { Lifetime } \\
\text { Prevalence } \\
(\%)\end{array}$ & $\begin{array}{l}\text { Past } 12 \\
\text { months } \\
\text { prevalence } \\
(\%)\end{array}$ \\
\hline $\begin{array}{l}\text { Australia, } \\
(\text { Mouzos and } \\
\text { Makkai, 2004) }\end{array}$ & $\begin{array}{l}6,677 \text { women aged } 18-69 \text {, } \\
\text { telephone criminal justice } \\
\text { survey }\end{array}$ & $\begin{array}{l}\text { Any violence from a } \\
\text { partner } \\
\text { Physical violence } \\
\text { Sexual violence }\end{array}$ & $\begin{array}{l}31 \\
12\end{array}$ & $\begin{array}{l}3 \\
1\end{array}$ \\
\hline $\begin{array}{l}\text { Australia (Taft } \\
\text { et al., 2004) }\end{array}$ & $\begin{array}{l}\text { 14,784 young women aged } \\
18-24 \text {, Australian } \\
\text { Longitudinal Study of } \\
\text { Women's Health (ALSWH) } \\
\text { postal survey }\end{array}$ & $\begin{array}{l}\text { Previous physical or sexual } \\
\text { violence from partner }\left(1^{\text {st }}\right. \\
\text { measure: } 1996) \\
\text { Previous physical or sexual } \\
\text { violence from partner }\left(2^{\text {nd }}\right. \\
\text { measure: } 2000)\end{array}$ & 10 & 5 \\
\hline $\begin{array}{l}\text { Australia } \\
\text { (Australian } \\
\text { Bureau of } \\
\text { Statistics - ABS, } \\
1996 \text { and } \\
2005)^{21,22}\end{array}$ & $\begin{array}{l}6,300 \text { women over age } 15, \\
\text { face to face survey (1996) } \\
11,800 \text { women over age } 15, \\
\text { telephone survey }(2005)\end{array}$ & $\begin{array}{l}\text { Physical/sexual violence } \\
\text { from partner (past/current) } \\
\text { Physical/sexual violence } \\
\text { from partner (past/current) }\end{array}$ & 15 & 2 \\
\hline $\begin{array}{l}\text { Brazil, } \\
\text { (Schraiber et al., } \\
2007)^{19}\end{array}$ & $\begin{array}{l}940 \text { urban women and } \\
1,188 \text { rural women aged } \\
15-49 \text {, face to face survey }\end{array}$ & $\begin{array}{l}\text { Physical violence } \\
\text { Sexual violence } \\
\text { Psychological violence }\end{array}$ & $\begin{array}{c}27 \text { (Urban) } \\
34 \text { (Rural) } \\
10 \text { (Urban) } \\
14 \text { (Rural) } \\
42 \text { (Urban) } \\
49 \text { (Rural) }\end{array}$ & $\begin{array}{l}\text { Non } \\
\text { available data }\end{array}$ \\
\hline
\end{tabular}

also estimated the serious health sequelae for abused young women ${ }^{20}$. These data and those of the mid-age ALSWH cohort were also used to estimate the consequences of IPV to health ${ }^{23}$. Using ALSWH data, other research by VicHealth, an Australian NGO (see below) found that IPV accounts for more health problems and premature deaths in women aged between 15-45 years in Australia, compared with any other avoidable risk factor.

Despite the differences between this set of studies (related to distinct methodological approaches, specific groups of women studied and different conceptual issues producing variable results), they show us that violence against women is a problem that Australia has in common with Brazil. The focus from this part forwards will be on the public policies and strategies adopted in Australia that aim to reduce IPV.

\section{A snapshot of current major public policies about IPV in Australia}

IPV is a criminal offence in Australia. It is also a policy area that retains bipartisan support in the Australian parliament. Australia's first National Women's Health Policy was recently reaffirmed ${ }^{4}$. It was developed in consultation with women across the country in 1989, named violence as a core concern and this policy and program focus on violence against women remains. At a federal level, this first meant funds for state provision of refuges and domestic violence services, including in some states, outreach workers who can support and counsel women in their homes until they are ready to leave. It has also meant funds for a welfare benefit - (e.g. sole parent's pension) which allows income for women if they choose to leave, priority rehousing in public accommodation and some legal aid. More recently, funds have also been allocated to support a national men's telephone advice line and accredited male behaviour change groups (BCG) 
for perpetrators, which combine a feminist analysis of violence with cognitive behavioural therapy. Accreditation of men's BCGs should include standards which mandate contact with partners and an emphasis on victim safety, but these are not always monitored. The most recent National Policy to reduce Violence against Women ${ }^{24}$ has a greater focus on prevention strategies (e.g. respectful gender relationships training in schools ${ }^{25}$, community gender education (e.g. in local and national football clubs) and national and local anti-violence media strategies). It also highlights the need for services to support children who have lived in families where IPV is perpetrated and needs of special populations, such as women with disabilities and those from indigenous ${ }^{26}$ or ethnic minorities.

In Australia, each state has specific public policies that result in particular approaches to dealing with IPV in health services. We will focus on Victoria, the second most populous state in Australia. Victoria prides itself on a whole of government approach to IPV, involving cross-departmental committees at the highest level. It includes the Justice, Health, Housing and Treasury departments ${ }^{27}$. In this context, Victorian police policies benefited from the state's first female Police Commissioner, who made strengthening police IPV procedures a priority. In consultation with local DV services, she and her staff: increased police training around IPV; brought in an arrest policy for perpetrators; piloted women remaining in the family home and removing the perpetrator; improved community policing; data collection; and consultation with DV services. Victoria has special DV magistrate courts, similar to 'Delegacias Especializadas de Atendimento à Mulher' - DEAM, in Brazil, where women can seek urgent intervention orders to keep perpetrators away; a Women's Legal Service; court support for disempowered victims; an Immigrant Women's DV Service and specialist refuges and services for indigenous women. Nevertheless, these strategies are often imperfect and perpetrators are not jailed until they breach an intervention order and this is common.

A Victorian strategy in the whole of government approach is an effort to ensure that all services (legal staff, police, refuge and family violence services staff and health workers) were trained with the same IPV concepts. Also that they understand the evidence about major risk factors and evidence-based strategies, through being involved with the 'Family Violence Risk Assessment and Risk Management Strategy ${ }^{28}$. The training and guidelines associated with this strat- egy aim to provide advice about how to provide culturally appropriate care in culturally and linguistically diverse communities, rural communities, women with disabilities, non heterosexual people, the elderly and respond to children's needs. The strategy recognises the key role of health workers and their training and resourcing is included in the strategy's budget.

A distinct approach to foster the development of innovative projects, studies and interventions, are those initiated by the non-government organisation 'VicHealth' (Victorian Health Promotion Foundation). VicHealth fosters research and action programs in several areas, strongly focusing on reducing mental ill-health arising from all forms of violence and racism. Some project areas of the related IPV primary prevention framework ${ }^{29}$ sponsored by this agency are: challenging community attitudes towards violence against women - comparing surveys to assess the shifts over time and evaluating IPV strategies; strengthening local government interventions, integrating violence prevention programs and policies at a local government level; approaches in indigenous communities and culturally and linguistically diverse communities; 'working with men and boys' to challenge sexism and machismo culture in partnership with the Australian Football League, and others.

\section{Australian health care responses to IPV}

The health damaging consequences of IPV have been extensively described ${ }^{1}$, and have become the target of specific public health policies around the world. Between the different policies, strategies and pilot projects to deal with IPV developed in Australia, we highlight below some of these strategies in the health arena.

\section{The first step: detecting women victims of IPV}

To better care for women victims of IPV, the first step is to identify where violence is occurring. 'Screening' women for IPV is one of the controversial strategies adopted as health policy in some states in Australia. 'Screening' or routine inquiry for IPV aims to detect early cases and is being seriously implemented, especially in primary care, emergency and prenatal care in particular, but also in rehabilitation ${ }^{30,31}$. Implicit in this policy is the assumption that increasing the identification of cases of women experiencing violence will enable support and appropriate inter- 
ventions and thus reduce exposure to violence and its health-damaging consequences ${ }^{31}$. In some instances, e.g. in antenatal care, psychosocial screening will attempt to cover a broad health agenda, trying to detect psychosocial problems as various as, child sexual abuse, alcohol and drug abuse, postnatal depression, social isolation, neglect and child abuse, and also IPV ${ }^{32}$. However, there are considerable problems with effective follow-up.

It has been argued ${ }^{32}$ that effective public health screening first requires adequate preparation for consequences after detection of women experiencing IPV. This requires ensuring that health professionals involved in screening have the expertise and support to respond appropriately. Poor responses can have negative penalties for victims, such as neglect of health care, inadequate medicalization, creating situations of despair or breaches of confidentiality, which can lead to more abuse ${ }^{33-35}$. Sustainable health system support is a critical prerequisite before screening should be introduced. It does not mean that health professionals should not be trained to 'case-find' - i.e. respond to symptomatic women with non-judgmental attitudes and referral to support, but effective health system response requires more careful strategies and coordination. Some Australian academics and activists argue emphatically that the most important challenge is not just to screen and detect cases of IPV, but rather to enhance the quality of health professionals' responses and evaluate the long-term impact for women.

\section{The second step: enhancing care for women through educating health professionals and evaluating new models of care}

There is considerable evidence of the role of health professionals in primary prevention, early identification and intervention in IPV cases ${ }^{1}$. In Australia, the ABS population studies found that after women turned to family and friends, the next person to whom they disclosed was a health professional ${ }^{21,22}$. A useful meta-analysis of qualitative studies ${ }^{36}$ documented women's hopes and expectations of health professionals around the world. The key role of health professionals' competence and professional confidentiality cannot be under-estimated. However, several authors $^{35,37}$ report that professionals have great difficulty in dealing with the issue. IPV is a complex social problem and not subject only to biomed- ical solutions, which calls for medical treatment and the improvement of injury and pain. Health professionals need support to improve this traditional care model, with training, resources and system support. It's worthy of mention that training and educating health professionals is not sufficient to change this situation; it is also necessary to address additional subjective factors such as personal sensitivity and social commitment, through a comprehensive intervention, so that clinicians become more confident of their skills in the identification, prevention and minimization of IPV ${ }^{38}$.

To try to provide different models of care, that could enable a more effective response to women victims of IPV and to contribute with the debate about education, qualification and the key role of health professionals, new approaches have been tested in Australia. Among these, some public health academics with an interest in IPV are now focussing their studies on testing potential interventions in the primary care system. The first intervention trial MOSAIC, (MOtherS' Advocates In the Community ${ }^{39}$ evaluated whether trained and supportive non-professional mentor mothers could reduce IPV and depression among pregnant and recent mothers identified by family doctors (General Practitioners - GPs) or Maternal and Child Health Nurses (MCHN). MCHN are based in public community centres and follow the development of the baby and mother's health through home visits and consultations in public health clinics. They see $>95 \%$ of all mothers with new babies. Together with GPs, they are local, accessible, universal and affordable. We hypothesize that the supportive role of mentor mothers could be similar to the role of Community Health Agents from the Brazilian Family Health Strategy. Both are health para-professionals, they don't need to be health sciences graduated; both are members of the local community and can build links to services for women in primary health care populations. However, mentor mothers are trained and supervised to provide sensitive confidential care and community links for women experiencing IPV.

One of MOSAIC's main findings was that despite a full day's IPV training and ongoing support, and clinical resources, health care professionals still found it difficult to identify and refer women, suggesting wider systemic issues at stake $^{39}$. This has led to two further randomised trials in primary care. The first, MOVE (Improving $\mathrm{MCH}$ nurse care for vulnerable mothers), is a screening trial to encourage a more supported 
and consistent $\mathrm{MCH}$ nurse response to IPV. Victoria has mandated $\mathrm{MCH}$ nurse screening when the baby is four weeks and has provided them with additional half day risk assessment training. MCH nurses expressed concern that husbands were still present at the four weeks consultation, women are more focussed on the baby and particularly, nurses don't feel they have a trust relationship yet with women to ask such a sensitive question. MOVE has provided nurses with supports at the local government level (nurse safety), formally linked them with FV services, provided them with within-team mentor support and supervision and requested screening at three/four months in a women's health focussed session with a written self-report questionnaire. The study is ongoing.

Another innovative project ongoing in this field is WEAVE (Women's evaluation of abuse and violence $)^{40}$, which is a randomised trial of 52 GP clinics, where women are screened for fear of their partner and invited after randomisation to the intervention arm, to up to six brief counselling sessions from their GP, who has been trained to deliver problem-solving and change-oriented supportive counselling. The study aims to improve women's use of safety behaviours where necessary and their quality of life and mental wellbeing. These studies aim to contribute to the growing but scarce evidence of what works to improve abused women's health and wellbeing when they are detected in health care systems ${ }^{41}$.

\section{The third step: \\ Providing responses to all family members}

While the most consistent public policies, training and guidelines to deal with IPV began by first addressing the needs of women, which are paramount, these do not sufficiently respond to the problem of men's violence or the needs of children, who can be victimised directly or indirectly. In Australia, public policies, services and health professionals have been involved in a greater effort to engage all family members involved in this issue. One specific and controversial example is 'Men's Behaviour Change Group Work' ${ }^{42}$ seen as an adjunct to vital criminal sanctions, but not instead of it. Many women do not want to leave their partner, but want the violence to stop and some men can be supported to change their behaviours with and without legal sanctions.

Health practitioners, including doctors, drug/ alcohol and mental health workers who see men with problematic behaviours, have been encour- aged to identify the safety and needs of the whole family ${ }^{33,43}$ whatever the family composition. The main challenge is to prioritise the safety and wellbeing of women and children. The principal objectives for health care professionals should include to identify male patients who abuse; to condemn the behaviour (not the man); to check their history (alcohol, drugs, weapons, mental health); and to assist the man to take responsibility for and to change his abusive behaviour, when possible and safe to do $\mathrm{so}^{43}$. In Australia there is a national telephone counselling and referral service specially dedicated for men 'Mensline', where men can seek advice for abusive behaviours, health care professionals can seek secondary consultation about, and refer men (and those who care for them) to both voluntary and also mandatory programs arising from criminal prosecution to promote non-abusive behaviour change.

The effectiveness of such programmes is difficult to measure and many exhibit a high dropout rate. Some evaluations demonstrated that a majority of female partners reported their lives had been improved after this approach, but at the same time, that such programmes are limited in their capacity to respond to male partner violence against women ${ }^{42,43}$.

There is a growing understanding of the early patterning of children's behaviour in families where IPV is perpetrated and the accumulating social and health damage from inter-generational violence. Australia is now focussing on preventing and reducing this damage in children and promoting resilience with prevention and early intervention strategies and individual and group therapeutic services for children and young people who have witnessed or experienced violence ${ }^{44}$.

\section{The fourth step: manage diversities}

IPV and women in same-sex relationships

In the field of IPV there are stereotypes and theoretical conceptualizations, which could imply that the problem only occurs in opposite-sex relationships ${ }^{45}$. However, there is now evidence of the rates of IPV among same-sex relationships similar to those in heterosexual relationships; and that this abuse is under-reported. Because of societal homophobia, community denial, and lack of gay/lesbian-sensitive and appropriate IPV resources, lesbian and gay victims of IPV frequently don't report their problem to authorities, nor do they seek help. Many lesbians and gays perceive law enforcement agencies and health services to be homophobic and heterosexist. 
Data on IPV against same-sex relationships women in Australia are almost non-existent. For the lesbian community it has been difficult to talk about violence within relationships, let alone the broader community, and there is little documented evidence available ${ }^{46}$. A UK study $y^{47}$ estimated that $40 \%$ of women experienced IPV at some time in a same sex relationship. This study with a sample of 421 non-heterosexual women also revealed that after abuse, $34 \%$ of these women searched for support with a therapist, while 11\% searched for a General Practitioner (GP).

Despite the lack of local studies about IPV on non-heterosexual relations, Australia is aware that this issue should not be neglected. Public policies are very explicit about including same sex relationships in their content ${ }^{24,28}$. They also highlight the key role that health professionals and the health system can perform to minimize trauma, avoiding homophobic attitudes, which could duplicate violence against these women.

\section{Ethnic diversity}

The WHO categorizes Australia as a country with low levels of violence compared to most other countries. However, Australia is a multi-ethnic country. The indigenous population are the Aboriginal and Torres Strait Islander people. Australian occupation brought with it European invasion and wars over indigenous lands, removal of Aboriginal children from their families, oppression, the unfamiliarity of alcohol and disease. Such dispossession, removal from lands and traditional ways of life and alcoholism has brought over-representation of Aboriginal families with problems of $\mathrm{FV}$, similar to those of colonised people in many countries.

With colonization, many European and Asian immigrants from different nationalities came to Australia. Little research has been undertaken analyzing the prevalence of IPV by women from culturally and linguistically diverse communities living in Australia. One study ${ }^{48}$ reported that Filipino women living in Australia were almost six times over-represented as victims of homicide, compared to other women, often immigrating as 'mail order' brides.

Facing this cultural diversity, the Australian Federal Government is implementing in health services a 'cultural competence policy'. Basically, 'cultural competence' is defined by the Australian National Health and Medical Research Council as ${ }^{49}$ : 'cultural and linguistic competence consisting of a set of congruent behaviours, attitudes and policies that come together in a system, agency, or among pro- fessionals that enables effective work in cross-cultural situations'. 'Competence' implies having the capacity to function effectively as an individual and an organization within the context of the cultural beliefs, behaviours and needs presented by consumers and their communities'.

Rodríguez and Saba ${ }^{50}$ add that to become culturally competent, health professionals need to: become comfortable with differences; acquire the ability to control and change false beliefs and assumptions; respect and appreciate the values and beliefs of those who are different; think flexibly and behave flexibly. Could health professionals be mindful and competent to manage this diversity? While studies have found that women's experience of violence and its health sequelae are remarkably similar, a culturally competent approach can be necessary for providing patient-centred care that encourages an individual response to victim/survivors, avoiding cultural stereotypes, but addressing women's concern about particular cultural issues, religious beliefs and traditions.

\section{Indigenous communities}

The indigenous population is estimated to be approximately 410.003 persons $s^{51}$, corresponding to over $2 \%$ of Australian's population. Despite the small proportion, indigenous women represent $15 \%$ of women's homicide in Australia. According to a National survey ${ }^{16}$, indigenous women reported higher levels of violence during their lifetime compared to non-indigenous women. The research suggests that indigenous women reported at least 3 times more physical and also at least 3 times more sexual violence compared to nonindigenous women. The Aboriginal Justice Coun$\mathrm{cil}^{146}$ also reported that $69 \%$ of assault cases against Aboriginal women were carried out by the spouse or partner.

Mulroney ${ }^{46}$ explains that Indigenous people conduct their activities in the 'public arena' and consequently, when altercations do occur within a family, violence may be harder to conceal and more likely to be drawn to the attention of external support services. The Violence in Indigenous Communities report ${ }^{52}$ also refers to multi-causal factors that could explain higher rates of violence in Aboriginal communities. Historical circumstances, like the loss of land and traditional culture, breakup of families, the disempowerment of traditional elders, easily acquired alcohol, collapse of community relationship systems and Aboriginal law, entrenched poverty and racism can be clearly factors underlying the exercise of violence. Aboriginal women have increasingly spearheaded strategies to 
increase safety in their communities, such as fighting for 'dry' lands (no alcohol) and creating refuges. Aboriginal people concerned about IPV in communities have persuaded state and territory governments to find strategies which are 'culturally safe', cultural competent (as mentioned above) and Aboriginal community-controlled.

The studies and public policies around IPV against Indigenous women in Australia call attention to this issue in the Brazilian context, which is also characterized by such ethnic diversity. The guarantee of rights for Brazilian Indigenous women regarding IPV is stated in the 'Maria da Penha Law', which assured all women opportunities and facilities to live without violence, regardless of class, race, ethnicity, sexual orientation, income, culture, educational level, age and religion. However studies focusing on this population group in Brazil are scarce ${ }^{53,54}$. There is also a gap in the systematization collection of data on IPV rates and femicide against women belonging to specific cultural backgrounds, such as Indigenous people. Souza et al. ${ }^{55}$ also observed the limitations of the Maria da Penha Law. For these authors, such public policy was designed around the needs of non-Indigenous women and transferring it to Indigenous communities would need intense reflection and consideration of their specific cultural systems.

\section{Final reflections}

This article attempted to show a brief panorama of Australian responses to IPV overall and in the health sector. We aim to encourage debates about the particularities in this scenario. However, we also recognize the limitations of this text, which can not convey the entire context. Our objective was to map a bit of the Australian scenario, describing some of its possibilities and challenges.

In this article we attempted to highlight how IPV is conceptualised and measured in Australia and some of the strategies adopted to minimize IPV. These include national bipartisan policies at federal, state and often local levels, an emphasis on prevention and early intervention in health services; innovative interventions to improve the responses of health professionals and the health system responses to IPV; the scheme for managing all family members, and the vital emphasis on diversity of responses to ethnic, cultural and sexual minorities.

All these strategies have challenging aspects and exchanging different experiences can be very valuable. All countries face different challenges and it's necessary to recognise that governments have different constraints on funding prioritised to this field. While it is honourable to pay respect to pioneering studies and work developed in each locality, it's also valuable to consider what the future priorities and the subsequent steps in this complex agenda should be. In order to fulfil our purpose with this article, which was to polemicize, problematize and stimulate debate, we present some questions that arose repeatedly during this study:

- Are national prevalence studies necessary and should they cover all the diversity within countries?

. Would a screening strategy be useful for other scenarios? If so, what are the preconditions of the health services and health professionals before implementing it?

- What are the local approaches to prevent and intervene in IPV adopted by health professionals? Do they consider all family members?

. How does the health system approach different diversities (sexual, cultural, ethnic) of IPV presently in other scenarios? What are the responses to IPV within Indigenous communities in other contexts?

. Are the current public health policies sufficient to respond to the needs of women victims of IPV and its ramifications in the family, community and society?

Australia presents thus an interesting scenario to think of violence against women. Undoubtedly, it shows advances in public policies, which must be observed more carefully. Of course, many dilemmas remain. It continues to be difficult to achieve sustained changes or indeed to support a majority of health care professionals to identify and support women experiencing violence, their children and families. Additionally the idea of a clinician working with violence against women becoming comfortable with difference and acquiring the ability to understand false beliefs, demonstrates the persistence of the multicultural ideology that 'accepts' and 'respects' the differences, but in reality how can establishing what is true and what is false be achieved? Tolerance and respect for diversity may actually be enclosed in an epistemological and clinical rationale advocated by the model? Finally, the frameworks described by us - and just described, without any intention or motivations - shows a set of devices (research, public policies, feminist debate, interpellation) in action which may be useful for further thinking and debate. 


\section{Collaborations}

MC Signorelli, A Taft and PPG Pereira contributed in the idealization, design and writing.

\section{Acknowledgments}

We acknowledge 'CAPES Foundation', from Brazil, that supported the scholarship funding for the Ph.D. student Marcos Claudio Signorelli to develop this study in Australia and Mother and Child Health Research, La Trobe University/ Melbourne for supporting him as a visiting scholar.

\section{References}

1. Krug EG, Dahlber LL, Mercy JA, Zwi AB, Lozano $\mathrm{R}$. World report on violence and health. Geneva: World Health Organization; 2002.

2. Garcia-Moreno C, Jansen HAFM, Ellsberg M, Heise $\mathrm{L}$, Watts $\mathrm{CH}$. Prevalence of intimate partner violence: findings from the WHO multi-country study on women's health and domestic violence. The Lancet 2006; 368(9543):1260-1269.

3. McGregor H, Hopkins A. Working for change: the movement against domestic violence. North Sydney (NSW): Allen, Unwin; 1991.

4. Department of Health and Aging. Development of a new national women's health policy - consultation discussion paper. Canberra [document on the In-

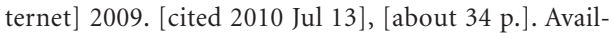
able from: http://www.health.gov.au/internet/main/ publishing.nsf/Content/phd-women-consult-discpaper.

5. Roberts G. The history of intimate partner abuse and health professionals. In: Roberts G, Hegarty K, Feder GS, editors. Intimate partner abuse and health professionals: new approaches to domestic violence. London: Churchill Livingstone; 2006. p.3-17

6. Das V. Violence, gender and subjectivity. Ann Rev Anthropol 2008; 37:283-299.

7. Scott J. Gender: A Useful Category of Historical Analysis. Am Hist Rev 1986; 91(5):1053-1075.

8. Grossi MP. Rimando amor e dor: reflexões sobre a violência no vínculo afetivo-conjugal. In: Grossi MP, Pedro JM, organizadores. Masculino, feminino e plural: o gênero na interdisciplinaridade. Florianópolis: Mulheres; 1998.

9. Saffioti HIB. Violência doméstica: questão de polícia e da sociedade. In: Corrêa M, organizador. Gênero e cidadania. Campinas: Núcleo de Estudos de Gênero - Pagu; 2001.

10. O'Donell C, Craney J. Family Violence in Australia. Melbourne: Longmann Cheshire; 1982.

11. Alexander R. Wife-battering: an Australian perspective. J Fam Violence 1993; 8(3):229-251.

12. Izumino WP, Santos CM. Violência contra as mulheres e violência de gênero: notas sobre estudos feministas no Brasil. Brasil [document on the Internet] 2008 [cited 2010 Ago 16], [about 16 p.]. Available from: http://www.nevusp.org/downloads/down083.pdf

13. Rosenberg ML, Fenley MA, Johnson D, Short L. Bridging prevention and practice: public health and family violence. Acad Med 1997; 72(Supl.):S13-8.

14. Saltzman L, Fanslow J, McMahon P, Shelley G. Intimate partner violence surveillance: uniform definitions and recommended data elements. $10^{\text {th }}$ ed. Atlanta: Centers for Disease Control and Prevention - National Center for Injury Prevention and Control; 2002.

15. Hegarty K. What is intimate partner abuse and how common is it? In: Roberts G, Hegarty K, Feder GS, editors. Intimate partner abuse and health professionals: new approaches to domestic violence. London: Churchill Livingstone; 2006. p. 19-40.

16. Mouzos J, Makkai T. Women's experiences of male violence: findings from the Australian component of the international violence against women survey (IVAWS). Canberra: Australian Institute of Criminology; 2004. 
17. Webster J, Sweet S, Stolz TA. Domestic violence in pregnancy: a prevalence study. Med J Aust 1994; 161(8):466-470.

18. Hegarty K, Bush R. Prevalence of partner abuse in women attending Australian General Practice: a cross-sectional survey. Aust N Z J Public Health 2002; 26(5):437-442.

19. Schraiber LB, D’Oliveira AFPL, França-Junior I, Diniz SC, Portella AP, Ludermir AB, Valença O, Couto MT. Prevalência da violência contra a mulher por parceiro íntimo em regiões do Brasil. Rev Saude Publ 2007; 41(5):797-807.

20. Taft A, Watson LF, Lee C. Violence against young Australian women and association with reproductive events: a crosssectional analysis of a national population sample. Aust N Z J Public Health 2004; 28(4):324-329.

21. Australian Bureau of Statistics. Women's Safety Survey. Canberra: ABS; 1996.

22. Australian Bureau of Statistics. Personal Safety Survey. Canberra: ABS; 2005.

23. Vos T, Astbury J, Piers LS, Magnus A, Heenan M, Stanley L, Walker L, Webster K. Measuring the impact of intimate partner violence in the health of women in Victoria, Australia. Bull World Health Organ 2006. 84(9): 739-744.

24. Department of Families, Housing, Community Services and Indigenous Affairs. Time for action: the national council's plan for Australia to reduce violence against women and their children, 2009-2021. Canberra [document on the Internet] 2009c. [cited 2010 Jul 13], [about 204 p.]. Available from: http:// www.apo.org.au/research/time-action-nationalcouncils-plan-australia-reduce-violence-againstwomen-and-their-childr

25. Flood M, Fergus L, Heenan M. Respectful relationships education: violence prevention and respectful relationships education in Victorian secondary schools. Department of Education and Early Childhood Development. Melbourne [document on the Internet] 2009. [cited $2010 \mathrm{Jul} 22$ ], [about 89 p.]. Available from: http://www.sexualethics.org.au/Publications/VIC_Schools_Report_RespectfulRelationships.pdf

26. Department of Planning and Community Development. Strong culture, strong peoples, strong families: towards a safer future for Indigenous families and communities - 10 year plan. $2^{\text {nd }}$ ed. Melbourne [document on the Internet] 2008. [cited $2010 \mathrm{Jul} 22$ ], [about 54 p.]. Available from: http://www.aborigina laffairs.vic.gov.au/web7/AAVMain.nsf/allDocs/ RWP58259791578CB296CA2574DD001C9CED? OpenDocument

27. Office of Women's Policy - Department of Planning and Community Development. A Right to respect: Victoria's plan to prevent violence against women 20102020. Melbourne [document on the Internet] 2009b [cited 2010 Jul 22], [about 47 p.]. Available from: http://www.women.vic.gov.au/web12/rwpgslib.nsf/ GraphicFiles/A+Right+to+Respect/\$file/DPCD+ Right+to+Repect+2010-2020+final+web\%5B1\% 5D.pdf
28. Family Violence Coordination Unit. Family violence risk assessment and risk management: supporting an integrated family violence service system. Melbourne [document on the Internet] 2007. [cited 2010 Jul 13], [about 93 p.]. Available from: http://www.women. vic.gov.au/web12/rwpgslib.nsf/GraphicFiles/Final RiskAssessmentandRiskManagementFramework/ \$file/FinalRiskAssessmentandRiskManagement Framework.pdf

29. Victorian Health Promotion Foundation. Preventing violence before it occurs: a framework and background paper to guide the primary prevention of violence against women in Victoria. Melbourne [document on the Internet] 2007b. [cited $2010 \mathrm{Jul}$ 13], [about 72 p.]. Available from: http://www.vichealth.vic.gov.au/ Resource-Centre/Publications-and-Resources/ Freedom-from-violence/Preventing-violencebefore-it-occurs.aspx

30. Howard J. Domestic violence screening: finding of a pilot project conducted by allied health staff in community health. Aust J Prim Health 2008; 14(1):43-51.

31. Ramsay J, Richardson J, Carter YH, Davidson LL, Feder GS. Should health professionals screen women for domestic violence? Systematic review. Brit Med J 2002; 325(7359):1-13.

32. Taft A. To screen or not to screen - is this the right question? Women against violence 2001; 10:41-46.

33. Taft A, Broom DH, Legge D. General practitioner management of intimate partner abuse and the whole family: qualitative study. Brit Med J 2004; 328(7440):618-621.

34. Taket A, Wathen CN, MacMillan H. Should health professionals screen all women for domestic violence? PLoS Med 2004; 1(1):e4.7-10.

35. Hegarty K, Taft A. Overcoming the barriers to disclosure and inquiry of partner abuse for women attending general practice. Aust N Z J Public Health 2001; 25(5):433-437.

36. Feder GS, Hutson M, Ramsay J, Taket AR. Women exposed to intimate partner violence - expectations and experiences when they encounter health care professionals: a meta-analysis of qualitative studies. Arch Intern Med 2006;166(1):22-37.

37. Cavalcanti MLT. Prevenção da violência doméstica na perspectiva dos profissionais da saúde da família. Cien Saude Colet 1999; 4(1):193-200.

38. Warshaw C, Taft A, Mccosker-Howard H. Educating health professionals: changing attitudes and overcoming barriers. In: Roberts G, Hegarty K, Feder GS, editors. Intimate partner abuse and health professionals: new approaches to domestic violence. London: Churchill Livingstone; 2006. p. 61-78.

39. Taft A, Small R, Hegarty K, Lumley J, Watson LF, Gold L. MOSAIC (MOthers' Advocates In the Community): protocol and sample description of a cluster randomised trial of mentor mother support to reduce intimate partner violence among pregnant or recent mothers. BMC Public Health 2009; 9:159. 
40. Hegarty K, Gunn JM, O’Doherty LJ, Taft A, Chondros P, Feder GS, Astbury J, Brown S. Women's evaluation of abuse and violence care in general practice: a cluster randomised controlled trial (WEAVE). BMC Public Health 2010; 10:2.

41. Ramsay J, Carter Y, Davidson L, Dunne D, Eldridge S, Feder G, Hegarty K, Rivas C, Taft A, Warburton A. Advocacy interventions to reduce or eliminate violence and promote the physical and psychosocial well-being of women who experience intimate partner abuse. Cochrane Database Syst Rev 2009; (3):CD005043.

42. Laing L. Responding to men who perpetrate domestic violence: controversies, interventions and challenges. Issues Paper No. 7. Sydney [document on the internet] 2002 [Cited 2011 Jun 15], [about 31 p.]. Available from: http://www.austdvclearinghouse. unsw.edu.au/issues_Papers.htm

43. Hegarty K, Taft A, Feder GS. Violence between intimate partners: working with the whole family. Brit Med J 2008; 337:346-351.

44. Smith J. What is the intimate impact of intimate partner abuse on children? In: Roberts G, Hegarty $\mathrm{K}$, Feder GS, editors. Intimate partner abuse and health professionals: new approaches to domestic violence. London: Churchill Livingstone; 2006.

45. Relf MV, Glass N. Gay and lesbian relationships and intimate partner abuse. In: Roberts G, Hegarty $\mathrm{K}$, Feder GS, editors. Intimate partner abuse and health professionals: new approaches to domestic violence. London, Churchill Livingstone; 2006.

46. Mulroney, J. Australian statistics on domestic violence. Australian Domestic and Family Violence Clearinghouse; Topic Paper n. 3. Canberra [document on the Internet] 2003. [cited 2011 Jun 15], [about 22 p.]. Available from: http://www.austdv clearinghouse.unsw.edu.au/topic_papers.htm

47. Donovan C, Hester M, Holmes J, Mccarry M. Comparing domestic abuse in same sex and heterossexual relationships. Bristol: University of Sunderland, Univesity of Bristol; 2006.

48. Cunneen C, Stubbs J. Migration, political economy and violence against women: the post immigration experiences of Filipino women in Australia. In: Freilich JD, Newman G, Shoham SG, Addad M, editors. Migration, Culture Conflict and Crime. Dartmouth: Ashgate; 2002.
49. National Health and Medical Research Council. Cultural competency in health: a guide for policy, partnerships and participation. Canberra [document on the Internet] 2005. [cited 2011 Jun 15], [about 85 p.]. Available from: http://www.nhmrc.gov.au/publications/ synopses/hp25syn.htm

50. Rodríguez MA, Saba G. Cultural competence and intimate partner abuse: health care and interventions. In: Roberts G, Hegarty K, Feder GS, editors. Intimate partner abuse and health professionals: new approaches to domestic violence. London: Churchill Livingstone; 2006. p. 181-197.

51. Trewin, D. Population distribution: Aboriginal and Torres Strait Islander Australians. Canberra: Australian Bureau of Statistics; 2001.

52. Memmot P, Stacy R, Chambers C, Keys C. Violence in Indigenous communities: full report. Canberra: Crime Prevention Branch, Attorney-General's Department; 2001.

53. Simonian L. Mulheres indígenas vítimas de violência. Papers do Núcleo de Altos Estudos Amazônicos. n. 30, Belém [document on the Internet] 1994. [cited 2011 Jun 01], [about 31 p.]. Available from: www.ufpa.br/naea/gerencia/ler_publicacao.php ?id $=85$

54. Verdum R, organizador. Mulheres indígenas, direitos e políticas públicas. Brasília: INESC; 2008.

55. Souza EL, Aleixo MT, Ruffeil MB. Maria(s) diversas, Pen(h)as diferentes: entre violências domésticas, gênero e diversidade cultural. In: Anais do $\mathrm{Fa}$ zendo Gênero 9; 2010; Florianópolis. p. 1-11.

Artigo apresentado em 15/03/2011

Aprovado em 16/06/2011

Versão final apresentada em 22/06/2011 